\title{
PENGEMBANGAN SUMBER DAYA MANUSIA DI YAYASAN PEMBANGUNAN MASYARAKAT SEJAHTERA KELURAHAN KEDAUNG PAMULANG TANGERANG SELATAN-BANTEN
}

\author{
Lucia Maduningtias*, Putri Nilam Kencana, Oki Iqbal Khair \\ Dosen Fakultas Ekonomi. Universitas Pamulang \\ Email* : madulucia07@gmail.com
}

\begin{abstract}
ABSTRAK
Tulisan ini bertujuan memberikan pemahaman kepada para peserta mengenai Pengembangan Sumber Daya Manusia .

Teknik pendekatan dilakukan dengan metode seminar dan simulasi secara langsung

Hasil kegiatan dapat mengembangkan sumber daya manusia Di Yayasan Pembangunan Masyarakat Sejahtera Kelurahan Kedaung Pamulang Tangerang Selatan-Banten
\end{abstract}

\section{Kata Kunci : Hakikat Sumber Daya Manusia, Pengembangan Sumber Daya Manusia}

\section{PENDAHULUAN}

Manajemen adalah suatu seni dalam perusahaan yang mengatur proses pemanfaatan Sumber Daya Manusia (SDM) dan sumber daya yang lain secara efisien dan efektit untuk tercapainya suatu tujuan .

Werther dan Davis dalam Edy Sutrisno (2014:4) menyatakan bahwa sumber daya manusia adalah " pegawai yang siap, mampu dan siaga dalam mencapai tujuan- tujuan organisasi ".

Menurut Edwin B. Filippo dalam CHR. Jimmy L.Gaol ( 2014:59) manajemen sumber daya manusia adalah proses merencanakan, mengorganisir, atau mengorganisasikan, mengarahkan, dan mengendalikan pengadaan, pengembangan, kompensasi, penyatuan, perawatan / pemeliharaan, dan pemisahan / pelepasan sumber daya manusia kepada tujuan-tujuan akhir individu organisasi dan masyarakat yang telah dicapai .

Yang dilakukan oleh perusahaan tentunya tujuan yang dicapai adalah tujuan yang dapat menguntungkan perusahaan tersebut. Manajemen Sumber Daya Manusia (MSDM) merupakan unsur man yang berarti manusia seperti yang dijelaskan diatas mengenai unsur- unsur manajemen.

MSDM dapat disebut juga sebagai manajemen kepegawaian dan manajemen personalia, yaitu ilmu yang mengatur manusia dalam suatu organisasi, supaya menjadi suatu pondasi untuk tercapainya suatu tujuan dalam suatu perusahaan.

Pengaruh lingkungan terhadap (nilai) terhadap MSDM tersebut terdiri dari beberapa bentuk outcome yang berupa undang- undang, instruktur- instruktur pimpinan esekutif, aturan- 
aturan pembuatan keputusan, serta interpretasi dan tinjauan dari lembaga yudikatif Perencanaan SDM bermaksud untuk memperkirakan permintaan SDM yang diperlukan agar dapat mewujudkan kegiatan bisnis yang terdapat dalam rencana strategi, rencana operasional dan program bisnis tahunan di lingkungan perusahaan.

Dewasa ini banyak perusahaan yang menggunakan perencanaan SDM . Tujuan umum pada suatu perusahaan adalah mengembangkan eksistensi yang dilihat dari sisi operasional perusahaan untuk meraih laba kompetitif secara berkelanjuan. Selain itu terdapat fungsi manajemen dalam arti makro pada umumnya adalah fungsi manajemen dan fungsi manajemen personalia yaitu fungsi operatif.

Manajemen adalah suatu alat untuK mencapai suatu tujuan perusahaan. Dengan membangun manajemen yang baik dalam perusahaan dapat memudahkan untuk tercapainya tujuan tersebut. Serta dibentuknya suatu manajemen suatu daya guna, hasil guna perusahaan dan unsur- unsur manajemen yang terdiri dari :

Man, money, method, machines, materials, dan market yang disingkat menjadi $6 \mathrm{M}$ juga dapat ditingkatkan. Manajemen artinya mengatur, yang diatur adalah unsur- unsur yang terdapat dalam manajemen tersebut yang dapat disingkat menjadi 6M. tujuannya adalah mencapai keberhasilan dalam mewujudkan tujuan. 6M harus diatur yang mengatur adalah pimpinan puncak, pimpinan madya, pimpinan supervisi supaya dalam melaksanaksanakan tujuan tersebut dapat bermanfaat dengan optimal dan terkoordinasi dengan baik dan diatur sesuai urutan fungsi manajemen.

Definisi manajemen itu sendiri adalah suatu seni dalam perusahaan yang mengatur proses pemanfaatan Sumber Daya Manusia (SDM) dan sumber daya yang lain secara evisien dan efektit untuk tercapainya suatu tujuan yang dilakukan oleh perusahaan tentunya tujuan yang dicapai adalah tujuan yang dapat menguntungkan perusahaan tersebut.

Pengaruh lingkungan terhadap nilai- nilai dalam MSDM, akan sangat nyata jika dilihat dari timbulnya nilai- nilai oleh Kondisi ekonomi, politik, sosial-budaya dan teknologi serta hukum. Pengaruh tersebut terdiri dari beberapa bentuk

Outcome yang berupa undang- undang, instruktur- instruktur pimpinan eksekutif, aturan- aturan pembuatan keputusan, serta interpretasi dan tinjauan dari lembaga yudikatif. Nilai- nilai yang bersaing ini dapat berpengaruh terhadap tindakan dan perilaku dari 3 lembaga yaitu lembaga esekutif, lembaka legeslatif dan lembaga yudikatif.

Nilai yang saling berkompetisi dapat di jadikan landasan dalam jiwa dan semangat dari berbagai bentuk peraturan dari berbagai lembaga manapun. Misalnya membentuk keputusan mengenai pandangan posisi baru atau peniadaan posisi tertentu.

1. Kondisi ekonomi

Kondisi Ekonomi ini sangat mempengaruhi tersedia atau tidak tersedianya lapangan kerja baik dari sektor publik maupun swasta, serta akan menyebabkan meningkatnya tuntutan- tuntutan akan pelayanan publik seperti bantuan sosial. 
2. Kondisi politik

Kondisi ini mempengaruhi dalam faktor- faktor MSDM. Orang cederung mempengaruhi fungsi - fungsi MSDM berdasarkan keyakinan politiknya. Pergantian pejabat dan pemimpin - pemimpin politik pastinya akan merubah suatu kebijakan, program dan pelayanan masyarakat prioritas program, maka dari itu sangat berpengaruh terhadap MSDM.

3. Kondisi sosial budaya

Perubahan yang terjadi pada lingkungan social budaya terdapat dalam berubahnya suatu karakteristik, demografis, pendidikan, keyakinan yangdmiliki masyarakat sangat berpengaruh terhadap MSDM. Misalnya, pertambahan usia manusia akan menambah jumlah orang tua.

4. Kondisi teknologi

Kemajuan teknologi seperti saat ini akan berpengaruh sangat besar terhadap tenaga kerja, dikarenakan dahulu yang kerja adalah manusia tetapi sekarang dengan semakin canggihnya teknologi pekerjaan dapat diselesaikan oleh mesin dengan waktu yang lebih efisien daripada dikerjakan oleh manusia. Maka dari itu kemajuan teknologi akan mengurangi jumlah tenaga kerja dan membuat masyarakant menjadi menganggur karena pekerjaan mereka digantikan oleh kecanggihan teknologi.

Berdasarkan latar belakang diatas maka kami tertarik melakukan kegiatan pengabdian masyarakat dengan tema "Pengembangan Sumber Daya Manusia Di Yayasan Pembangunan Masyarakat Sejahtera Kelurahan Kedaung Pamulang Tangerang Selatan-Banten"

\section{RUMUSAN MASALAH}

Berdasarkan latar belakang diatas dapat dirumuskan permasalahan sebagai berikut : Bagaimana Pengembangan Sumber Daya Manusia Di Yayasan Pembangunan Masyarakat Sejahtera Kelurahan Kedaung Pamulang Tangerang Selatan-Banten?

\section{TUJUAN}

Tujuan yang ingin dicapai dalam kegiatan ini adalah : Untuk memberikan pemahaman kepada para peserta mengenai Pengembangan Sumber Daya Manusia Di Yayasan Pembangunan Masyarakat Sejahtera Kelurahan Kedaung Pamulang Tangerang Selatan-Banten

\section{KEGIATAN}

Sasaran dari program Pengabdian Masyarakat yang akan kami lakukan di Yayasan Pembangunan Masyarakat Sejahtera Jln. Mesjid Darusallam no.40 RT/RW 09/04 kelurahan Kedaung Pamulang -Tangerang Selatan, tanggal 29-31 Mei 2018 


\section{APLIKASI}

\section{A. Yayasan Pembangunan Masyarakat Sejahtera}

YPMS adalah Yayasan Pembangunan Masyarakat Sejahtera yang bergerak di bidang pengadaan pendidikan dan kepesantrenan untuk anak anak yatim piatu dan kaum dlua'fa. Sebuah Yayasan Non Profit yang mempedulikan pendidikan dan pembinaan mental generasi Bangsa.

Idea dasar berdirinya YPMS berawal dari kegiatan pengajian yang intens sebagai pembinaan mental bagi Kaum Muslimin dan Muslimat pada tahun 1985, Dengan Pendidikan, anak anak diharapkan dapat menjadi bagian masyarakat yang mampu memberikan kontribusi buat kemaslahatan umat, mengingat persaingan global menuntut SDM yang berkualitas dan berdedikasi. Manusia kreatif dan inovatif dan berdisiplin dengan Ilmu Pengetahuan.

Dan dengan Pesantren, anak anak diharapkan dapat menjadi Hamba Allah yang selalu taat dan beribadah / berbakti kepada Tuhan Yang Maha Esa. Tidak terpengaruh oleh kegiatan dan keadaan ketika kelak berada di tengah masyarakat. Selalu mengisi barisan terdepan dalam memperjuangkan harkat dan martabat sebagai manusia yang mandiri dan beragama.

Pendidikan Nasional yang bertujuan menciptakan generasi yang bertaqwa kepada Tuhan Yang Maha Esa, mencerdaskan bangsa yang berintegritas dan taat pada Nusa dan Bangsa, ditambah banyaknya pengaruh budaya asing yang bisa merusak generasi bangsa.

Generasi yang tangguh, terampil dan berakhlak mulia serta memiliki integritas yang tinggi adalah dambaan semua kalangan. Berangkat dari krisis multidimensional yang dialami oleh bangsa ini sudah sepatutnya kita mempersiapkan generasi tersebut sebagai pelanjut dari estapet kepemimpinan di negeri ini. Dampak dari krisis ini tidak sedikit generasi kita ini, yang mengalami nasib kurang baik, sekolah terputus, dan hidup pas-pasan

Pada tahun 1989 membentuk "YAYASAN PEMBANGUNAN MASYARAKAT SEJAHTERA" yang disingkat YPMS. Sebuah Panti Asuhan yang bukan saja menjadi tempat anak anak berkumpul dan mengkaji ilmu Agama, namun anak anak juga dididik dengan pendidikan formal dengan tetap tidak meninggalkan kegiatan utama, yaitu beribadah dan belajar / mengaji.

untuk mempersiapkan generasi penerus yang beribadah, handal, dan tangguh tidaklah mudah. Karena sebagaimana kita ketahui bersama tingkat kehidupan bagi setiap orang pasti berbeda. Biaya hidup yang besar, menyebabkan keluarga menentukan pilihan skala prioritas dalam penentuan pembiayaan kehidupan, bertahan hidup, menjadi prioritas pembiyaan, sementara pendidikan menjadi hal yang di-nomordua-kan dalam pembiayaan hidup. Dibutuhkan pengorbanan mori dan materiil dari Kaum Muslimin yang terpanggil jiwanya untuk memikul tanggung jawab bersama.

Sebagai Panti / Lembaga yang menyantuni Kaum Dluafa, YPMS mengajak Kaum Muslimin dan Muslimat untuk mewujudkan cita-cita luhur membentuk generasi yang handal dan siap menjawab tantangan zaman. Dan menciptakan 
sebuah panti yang baik dan memenuhi standar kelayakan, maka salah satu syarat yang diperlukan adalah terpenuhinya kebutuhan dasar (makan, pakaian, pendidikan dan kesehatan) anak asuhnya. Saat ini (th 2018), YPMS menampung 236 (dua ratus tiga puluh enam) anak asuh dan 22 (dua puluh dua) pengurus.

\section{B. Sumber Daya Manusia}

Sumber daya manusia (SDM) adalah salah satu faktor yang sangat penting bahkan tidak dapat dilepaskan dari sebuah organisasi, baik institusi maupun perusahaan. SDM juga merupakan kunci yang menentukan perkembangan perusahaan. Pada hakikatnya, SDM berupa manusia yang dipekerjakan di sebuah organisasi sebagai penggerak, pemikir dan perencana untuk mencapai tujuan organisasi itu.

Dewasa ini, perkembangan terbaru memandang karyawan bukan sebagai sumber daya belaka, melainkan lebih berupa modal atau aset bagi institusi atau organisasi. Karena itu kemudian muncullah istilah baru di luar H.R. (Human Resources), yaitu H.C. atau Human Capital. Di sini SDM dilihat bukan sekadar sebagai aset utama, tetapi aset yang bernilai dan dapat dilipatgandakan, dikembangkan (bandingkan dengan portfolio investasi) dan juga bukan sebaliknya sebagai liability (beban,cost). Di sini perspektif SDM sebagai investasi bagi institusi atau organisasi lebih mengemuka.

Pengertian SDM dapat dibagi menjadi dua, yaitu pengertian mikro dan makro. Pengertian SDM secara mikro adalah individu yang bekerja dan menjadi anggota suatu perusahaan atau institusi dan biasa disebut sebagai pegawai, buruh, karyawan, pekerja, tenaga kerja dan lain sebagainya. Sedangkang pengertian SDM secara makro adalah penduduk suatu negara yang sudah memasuki usia angkatan kerja, baik yang belum bekerja maupun yang sudah bekerja.

Secara garis besar, pengertian Sumber Daya Manusia adalah individu yang bekerja sebagai penggerak suatu organisasi, baik institusi maupun perusahaan dan berfungsi sebagai aset yang harus dilatih dan dikembangkan kemampuannya.

\section{Pengembangan Sumber Daya Manusia}

Pengembangan sumber daya manusia bertujuan menghasilkan kerangka kerja yang bertalian secara logis dan komprehensif untuk mengembangkan lingkungan dimana karyawan didorong belajar berkembang (Sedarmayanti, 2008:167).

Pengembangan sumber daya manusia adalah upaya berkesinambungan meningkatkan mutu sumber daya manusia dalam arti yang seluas-luasnya, melalui pendidikan, latihan, dan pembinaan (Silalahi, 2000:249).

Pengembangan sumber daya manusia bertujuan menghasilkan kerangka kerja yang bertalian secara logis dan komprehensif untuk mengembangkan lingkungan dimana karyawan didorong belajar berkembang (Sedarmayanti, 2008:167). 
Pengembangan sumber daya manusia adalah upaya berkesinambungan meningkatkan mutu sumber daya manusia dalam arti yang seluas-luasnya, melalui pendidikan, latihan, dan pembinaan (Silalahi, 2000:249).

Pengembangan sumber daya manusia juga merupakan cara efektif untuk menghadapi beberapa tantangan, termasuk keusangan atau ketertinggalan karyawan, diversifikasi tenaga kerja domestik dan internasional. Dengan dapat teratasinya tantangan-tantangan (affirmative action) dan turnover karyawan, pengembangan sumber daya manusia dapat menjaga atau mempertahankan tenaga kerja yang efektif.

Pengembangan merupakan suatu cara efektif untuk menghadapi beberapa tantangan yang di hadapi oleh banyak organisasi besar. Tantangan-tantangan ini mencakup keusangan karyawan, perubahan-perubahan sosioteknis dan perputaran tenaga kerja. Kemampuan untuk mengatasi tantangan-tantangan tersebut merupakan faktor penentu keberhasilan departemen personalia dalam mempertahankan sumber daya manusia yang efektif (Handoko, 2008:117).

Pengembangan (development) adalah penyiapan individu untuk memikul tanggung jawab yang berbeda atau yang lebih tinggi di dalam organisasi (Simamora, 2006:273). Pengembangan biasanya berhubungan dengan peningkatan kemampuan intelektual atau emosional yang diperlukan untuk menuaikan pekerjaan yang lebih baik. Pengembangan berpijak pada fakta bahwa seorang karyawan akan membutuhkan pengetahuan, keahlian, dan kemampuan yang berkembang supaya bekerja dengan baik dalam suksesi posisi yang dijalani selama karirnya. Persiapan karir jangka panjang dari seorang karyawan untuk serangkaian posisi inilah yang dimaksud dengan pengembangan karyawan.

Pengembangan mempunyai lingkup yang lebih luas. Pengembangan lebih terfokus pada kebutuhan umum jangka panjang organisasi. Hasilnya bersifat tidak langsung dan hanya dapat diukur dalam jangka panjang. Pengembangan juga membantu para karyawan untuk mempersiapkan diri menghadapi perubahan dipekerjaan mereka yang dapat diakibatkan oleh teknologi baru, desain pekerjaan, pelanggan baru, atau pasar produk baru.

\section{Bentuk-Bentuk Pengembangan Sumber Daya Manusia}

Dalam program pengembangan harus dituangkan sasaran, kebijaksanaan prosedur, anggaran, peserta, kurikulum, dan waktu pelaksanaannya. Program pengembangan harus berprinsipkan pada peningkatan efektivitas dan efisiensi kerja masing-masing karyawan pada jabatannya. Program pengembangan suatu organisasi hendaknya diinformasikan secara terbuka kepada semua karyawan atau anggota supaya mereka mempersiapkan dirinya masing-masing.

Bentuk pengembangan dikelompokkan atas; Pengembangan secara informal,dan pengembangan secara formal (Hasibuan, 2008:72). Untuk lebih jelasnya kedua jenis pengembangan di atas dapat diuraikan sebagai berikut :

\section{a. Pengembangan secara informal}

Pengembangan secara informal yaitu karyawan atas keinginan dan usaha sendiri melatih dan mengembangkan dirinya dengan mempelajari buku-buku 
literatur yang ada hubungannya dengan pekerjaan atau jabatannya. Pengembangan secara informal menunjukkan bahwa karyawan tersebut berkeinginan keras untuk maju dengan cara meningkatkan kemampuan kerjanya. Hal ini bermanfaat bagi perusahaan karena produktivitas kerja karyawan semakin besar, di samping efisiensi dan produktivitasnya juga semakin baik.

\section{b. Pengembangan secara formal}

Pengembangan secara formal yaitu karyawan ditugaskan perusahaan untuk mengikuti pendidikan atau latihan, baik yang dilakukan perusahaan maupun yang dilaksanakan oleh lembaga-lembaga pendidikan atau pelatihan. Pengembangan secara formal dilakukan di perusahaan karena tuntutan pekerjaan saat ini ataupun masa datang, sifatnya non karier atau peningkatan karier seorang karyawan.

Pelatihan dan pengembangan (training dan development) memang memerlukan biaya yang cukup besar, namun investasi di bidang manusia tersebut (human investment) akhirnya akan menyumbangkan produktivitas yang sangat tinggi bagi organisasi atau perusahaan. Untuk itu organisasi atau perusahaan tentunya akan memetik laba yang berlipat ganda di waktu yang akan datang.

Program pengembangan karyawan hendaknya disusun secara cermat dan didasarkan kepada metode-metode ilmiah serta berpedoman kepada keterampilan yang dibutuhkan perusahaan saat ini maupun untuk masa depan. Pengembangan harus bertujuan untuk meningkatkan kemampuan teknis, teoritis, konseptual, dan moral karyawan supaya produktivitas kerjanya baik dan mencapai hasil yang optimal.

\section{E. Tujuan Pengembangan Sumber Daya Manusia}

Setiap organisasi apapun bentuknya senantiasa akan berupaya dapat tercapainya tujuan organisasi yang bersangkutan dengan efektif dan efisien. Efisiensi maupun efektivitas organisasi sangat tergantung pada baik buruknya pengembangan sumber daya manusia atau anggota organisasi itu sendiri. Ini berarti bahwa sumber daya manusia yang ada dalam organisasi tersebut secara proporsional harus diberikan latihan dan pendidikan yang sebaik-baiknya, bahkan harus sesempurna mungkin.

Pengembangan pada umumnya lebih bersifat filosofis dan teoritis, dibandingkan dengan kegiatan pelatihan. Lagi pula pengembangan lebih diarahkan untuk golongan manajer, sedangkan program pelatihan ditujukan untuk golongan non manajer. Meskipun keduanya ada perbedaan, namun perlu disadari bahwa baik latihan (training) maupun pengembangan (development) keduanya menekan peningkatan keterampilan ataupun kemampuan dalam human relations

Dari uraian di atas jelas, bahwa tujuan organisasi atau perusahaan akan dapat tercapai dengan baik apabila karyawan dapat menjalankan tugasn ya dengan efektif dan efisien. Sehingga untuk itu usaha pengembangan sumber daya manusia dalam organisasi/perusahaan yang bersangkutan sangatlah diperlukan. Dengan demikian dapat ditarik kesimpulan, bahwa tujuan pengembangan sumber daya manusia termaksud adalah untuk memperbaiki efektivitas dan efisiensi kerja 
mereka dalam melaksanakan dan mencapai sasaran program-program kerja yang telah ditetapkan. Perbaikan efektivitas dan efisiensi karyawan dapat dicapai dengan meningkatkan: pengetahuan, keterampilan dan sikap karyawan terhadap tugastugasnya.

Tujuan pengembangan karyawan adalah untuk memperbaiki efektivitas kerja karyawan dalam mencapai hasil-hasil kerja yang telah ditetapkan. Perbaikan efektivitas kerja dapat dilakukan dengan cara memperbaiki pengetahuan karyawan, keterampilan karyawan maupun sikap karyawan itu sendiri terhadap tugas-tugasnya (Heidjrachman dan Husnan, 2004:74).

Pengembangan karyawan bertujuan dan bermanfaat bagi perusahaan, karyawan, konsumen, atau masyarakat yang mengkonsumsi barang/jasa yang dihasilkan perusahaan. Menurut Tohardi (2008 : 70) tujuan pengembangan adalah:

1. Produktivitas. Dengan pengembangan, produktivitas kerja karyawan akan meningkat, kualitas dan kuantitas produksi akan semakin baik, karena technical skill, human skill dan managerial skill karyawan akan semakin baik.

2. Efisiensi. Pengembangan karyawan untuk meningkatkan efisiensi sumber daya manusia, waktu, bahan baku dan mengurangi ausnya mesin-mesin. Pemborosan berkurang, biaya produksi relatif kecil sehingga daya saing perusahaan semakin kecil.

3. Kerusakan. Pengembangan karyawan bertujuan untuk mengurangi kerusakan barang, produksi dan mesin-mesin karena karyawan semakin ahli dan terampil dalam melaksanakan pekerjaannya.

4. Kecelakaan. Pengembangan bertujuan untuk mengurangi tingkat kecelakaan karyawan, sehingga jumlah biaya pengobatan yang keluarkan perusahaan berkurang. Pelayanan. Pengembangan bertujuan untuk meningkatkan pelayanan yang lebih baik dari karyawan kepada nasabah perusahaan, karena pemberian pelayanan yang lebih baik merupakan daya penarik yang sangat penting bagi rekanan-rekanan perusahaan bersangkutan.

5. Moral. Dengan pengembangan, moral karyawan akan lebih baik karena keahlian dan keterampilannya sesuai dengan pekerjaannya sehingga merek antusias menyelesaikan pekerjaannya dengan baik.

6. Karier. Dengan pengembangan, kesempatan untuk meningkatkan karier karyawan semakin besar, karena keahlian, keterampilan dan prestasi kerjanya lebih baik, promosi ilmiah biasanya didasarkan kepada keahlian dan prestasi kerja seseorang.

7. Konseptual. Dengan pengembangan, manajer akan semakin cakap dan cepat dalam mengambil keputusan yang lebih baik, karena technical skill, human skill dan managerial skill nya lebih baik.

8. Kepemimpinan. Dengan pengembangan, kepemimpinan seorang manajer akan lebih baik, human relationsnya lebih luas, motivasi lebih terarah sehingga pembinaan kerja sama vertikal dan horizontal semakin harmonis. 
9. Balas Jasa. Dengan pengembangan, balas jasa (gaji, upah, intensif dan benefit) karyawan akan meningkat karena prestasi kerja mereka semakin besar.

10. Konsumen. Pengembangan karyawan akan memberikan manfaat yang lebih baik bagi masyarakat konsumen karena mereka akan memperoleh barang atau pelayanan yang lebih bermutu.

Dengan memperhatikan tujuan pengembangan tersebut di atas dapat disimpulkan pula manfaat atau fungsi suatu program pengembangan sumber daya manusia dalam suatu organisasi. Yang jelas adalah dengan latihan dan pendidikan seorang lebih mudah melaksanakan tugasnya, sehingga akan lebih positif dalam menyumbang tenaga dan pikiran bagi organisasi.

\section{STRATEGI}

Dalam kegiatan ini menggunakan teknik seminar, simulasi, pendekatan persuasif kepada peserta untuk mengembangakan sumber daya manusia dimasa yang akan datang khususnya di Yayasan Pembangunan Masyarakat Sejahtera

\section{PENUTUP}

Kegiatan ini diharapkan dapat menambah wawasan mengenai hakikat sumber daya manusia dan pengembangan sumberdaya manusia terutama di Yayasan Pembangunan Masyarakat Sejahtera

\section{DAFTAR REFERENSI}

Hasibuan, S.P Malayu, 2002, Organisasi dan Motivasi : Dasar Peningkatan Produktifitas, Jakarta : Bumi Aksara.

Sutrisno , Edy, 2014. Manajemen Sumber Daya Manusia, Jakarta :Kencana Prenada Media Grup.

http://ypmskedaung.blogspot.com/2018/02/yayasan-pembangunan$\underline{\text { masyarakat.html }}$

https://id.wikipedia.org/wiki/Sumber_daya_manusia

https://www.kajianpustaka.com/2016/02/pengembangan-sumber-daya$\underline{\text { manusia.html }}$ 


\section{DOKUMENTASI FOTO KEGIATAN}
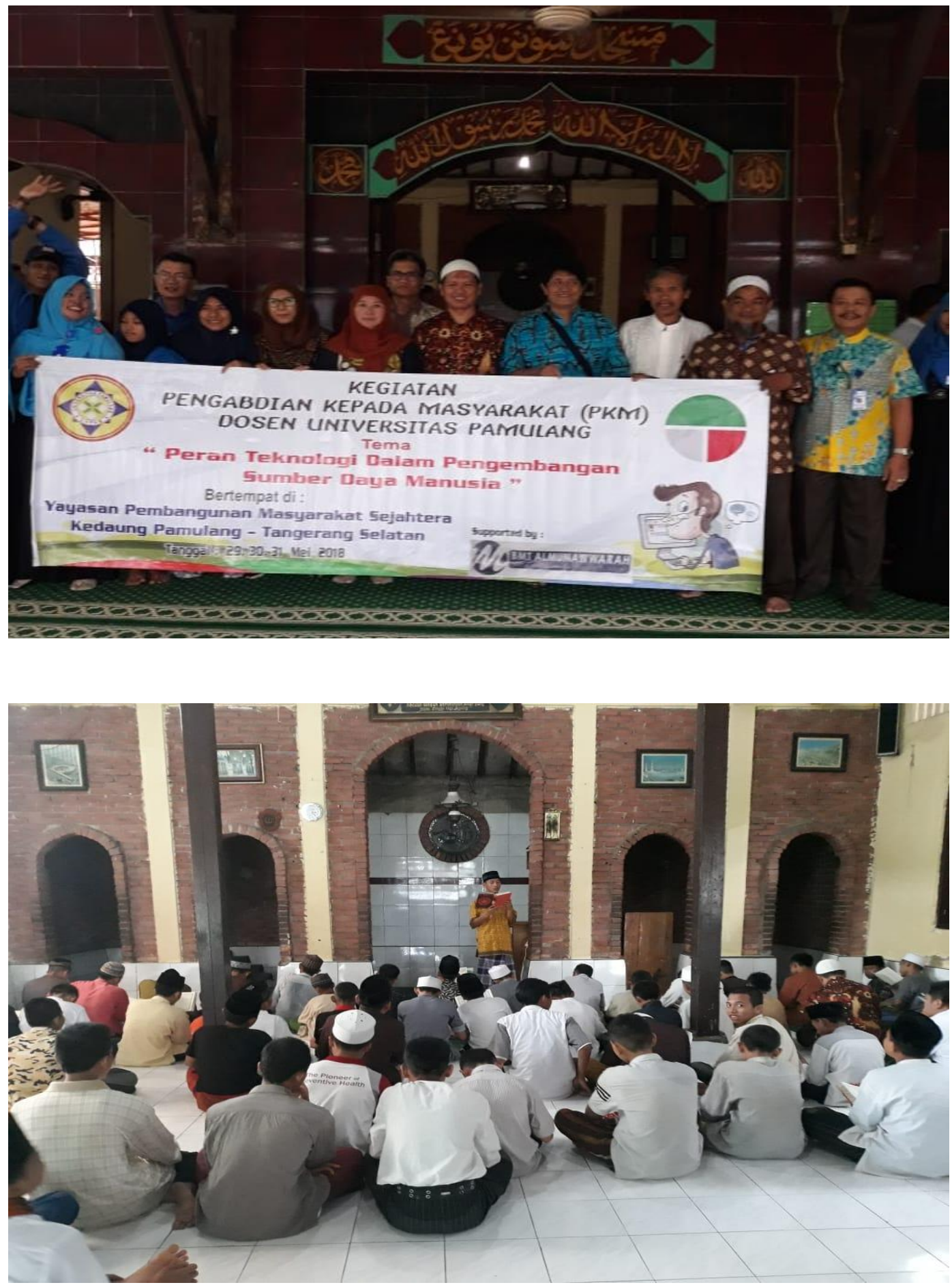